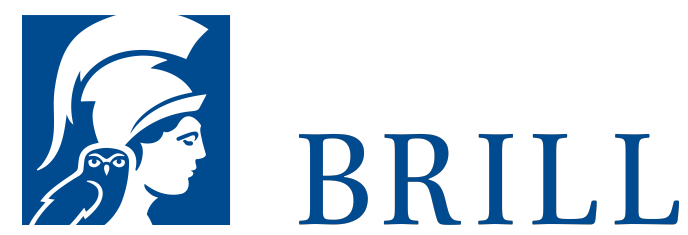

\title{
Perception and Cognition
}

\author{
Analyzing Object Recognition
}

Author: Ulrike Pompe

The intrinsic relation between rationality or thought on the one hand and sensory information processing or perception on the other hand is a classical topic in the philosophy of mind. This work contributes to this traditional debate by introducing an interdisciplinary framework, in which the relation between perception and cognition can be explored from a philosophical point of view and, at the same time, on the basis of the latest findings from empirical perception research. Discussing the case of visual object recognition, the proposed model allows us to differentiate between a variety of perceptual phenomena and to clarify our understanding of the role of concepts within perception. As such, it takes a stand in the debate about the conceptuality of perceptual content, exemplifying at which stage of perception and by virtue of which mechanisms perceptual experience becomes enriched or even influenced by prior knowledge or cognition in general. The final chapter is dedicated to the discussion of face perception, its disorders and underlying mechanisms.

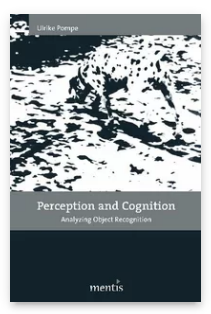

Pages: 189

Seiten

Language:

English

Subjects:

General,

Philosophy

Publisher: Brill | mentis

E-Book (PDF)

Released online:

o1 Jul 2011

ISBN: 978-3-

95743-886-7

List price

USD $\$ 52.00$

Paperback

Publication date:

o1 Jul 2011

ISBN: 978-3-

89785-735-3

List price

USD $\$ 52.00$ 
For more information see brill.com

Order information: Order online at brill.com +44330 333 0049 | customerservices@brill.com Submission information: brill.com/authors

Titles published by Brill | Fink, Brill | mentis or Brill | Schöningh: +49(o)715413279216| brill@brocom.de 